\title{
Cirurgias de implantes guiadas por computador podem se tornar progressivamente mais freqüentes e precisas
}

\author{
Waldemar Daudt Polido
}

A busca incessante dos cirurgiões por cirurgias mais rápidas e precisas, e com melhores pós-operatórios, levou ao desenvolvimento de inúmeros softwares e hardwares (equipamentos e instrumentos) para a realização de cirurgias guiadas por computador, as chamadas "cirurgias virtuais". O princípio básico consiste em realizar uma tomografia computadorizada no paciente, tendo pontos de referência, como a própria prótese, para a captura de imagens em um PC. Essas imagens são manipuladas em um programa específico - tal como o NobelGuide, o Simplant ou o DentalSlice - que permite não só a colocação dos implantes no programa, mas, a partir disso, a confecção de um guia cirúrgico de alta precisão, levando à possibilidade de realizar cirurgias sem retalhos, para a colocação dos implantes e da prótese em carga imediata nos pacientes. Recentemente, uma divulgação intensa desse tipo de programa passou a ser feita em congressos e até mesmo em programas de mídia, como rádio e televisão, atraindo mais pacientes. Widmann e Bale $^{1}$ revisaram a literatura a respeito, buscando elucidar quais os diferentes fatores e quais as limitações que influenciam a precisão desse tipo de tratamento. Em seu artigo, eles relatam que a precisão dos sistemas de cirurgia guiada ou cirurgia virtual para a colocação de implantes dentários depende de uma série de fatores cumulativos e interativos, que podem levar a erros. Estes podem estar presentes: no processo de aquisição da imagem, no processo do registro (transforma- ção imagem-físico); na navegação do software; na produção do guia cirúrgico e no erro humano. Os autores recomendam a observância de uma distância de segurança equivalente a pelo menos o desvio máximo de cada sistema.

Comparadas à técnica tradicional, a colocação do implante com auxílio do computador requer um investimento e esforço substancialmente maiores, mas parece propiciar um bom resultado, no sentido de eliminar erros e sistematizar a reprodução de tratamentos com sucesso. Também permite a proteção de estruturas anatômicas críticas, bem como vantagens estéticas e funcionais que advém da colocação do implante no local determinado pela prótese. Baseado em dados clínicos, a cirurgia virtual não é indicada em casos fáceis, com suficiente orientação anatômica e volume ósseo. Entretanto, pode ser indicada em casos onde uma tomografia computadorizada esteja recomendada como meio diagnóstico, quando a colocação precisa do implante for imperativa, e quando implantes com comprimentos mais longos forem desejados para o uso otimizado do osso disponível. Todavia, estudos clínicos prospectivos ainda são necessários para examinar mais aspectos do sucesso do tratamento e confirmar o valor dessa estratégia, justificando a dose de radiação adicional e os custos dessa tecnologia. 1. WIDMANN, G.; BALE, R. J. Accuracy in computer-aided
implant surgery - a review. Int. J. Oral Maxillofac. Implants,
Chicago, v. 21, no. 2, p. 305-13, Mar./Apr. 2006. 


\section{Reconstrução óssea por meio do uso de rhBMP-2}

Um dos sonhos de qualquer cirurgião, ao ter que reconstruir algum tipo de defeito ósseo, é a possibilidade de simplesmente abrir um vidro da prateleira, retirar um material indutor ósseo, implantar no paciente e apenas aguardar até que o osso esteja formado, para que os implantes sejam colocados. Finalmente, esse dia parece estar chegando.

Em 9 de março de 2007 a FDA aprovou as novas indicações para o uso do Infuse (Medtronic), como alternativa ao osso autógeno em áreas de enxerto de seio maxilar e para aumento de rebordo alveolar pós-exodontia. O produto consiste em uma apresentação da proteína morfogenética humana recombinante 2 (rhBMP-2 - recombinant human Bone Morphogenetic Protein-2) e promove a diferenciação celular de osteoblastos, assim que é implantado. Em forma de líquido, é aplicado a uma esponja de colágeno absorvível, que serve de arcabouço para o crescimento ósseo. À medida que o local cicatriza, a esponja reabsorve e dá lugar ao osso.

A aprovação para as aplicações bucomaxilofaciais foi baseada em dados de 5 estudos clínicos envolvendo 312 pacientes. Em um estudo randomizado em pacientes requerendo aumento ósseo alveolar, o rhBMP-2 mostrou-se tão efetivo quanto o osso autógeno, mas associado a menos dor e complicações.

Em um estudo pivotal, 83\% dos que receberam o enxerto com rhBMP-2 $(\mathrm{n}=99)$ produziram osso em quantidade suficiente para suportar implantes sem a necessidade de aumentos adicionais, e 93\% dos que receberam os implantes tiveram suas funções de mastigação sobre os implantes controladas por 6 meses, sem complicações.
O enxerto por rhBMP-2 havia sido previamente aprovado pela FDA para uso em certos procedimentos de fusão de espinha lombar e reparo de fratura de tíbia.

Em um estudo recente, Jovanovic et al. ${ }^{2}$ testaram o uso de rhBMP-2 em combinação com membranas de regeneração óssea guiada (ROG) para defeitos alveolares graves. Concluíram que o uso de rhBMP-2 é uma excelente alternativa ao uso de enxerto autógeno e ROG, com 100\% de formação óssea. Mas a combinação da rhBMP-2 com ROG não traz maiores vantagens, podendo haver complicações com seroma e formação de lacunas, além do potencial problema de exposição da membrana.

O produto ainda está disponível somente nos EUA, para cirurgiões treinados na técnica, e ainda a um preço relativamente elevado, variando de US\$ 4.000,00 a US\$ 12.000,00, dependendo da quantidade.

\section{REFERÊNCIAS}

1. BOYNE, P. J. et al. De novo bone induction by recombinant human bone morphogenetic protein (rhBMP-2) in maxillary sinus floor augmentation. J. Oral Maxillofac. Surg., Philadelphia, v. 63, no. 12, p. 1693-707, 2005.

2. JOVANOVIC, S. A. et al. Bone reconstruction following implantation of rhBMP-2 and guided bone regeneration in canine alveolar ridge defects. Clin. Oral Implant Res., Copenhagen, v. 18, no. 2, p. 224-230, Apr. 2007.

* Doutor em Cirurgia e Traumatologia Bucomaxilofacial (CTBMF) pela PUCRS, com Residência em CTBMF na Universidade do Texas, Southwestern Medical Center at Dallas, EUA. Fellow do ITI, International Team for Implantology, e atual Chairman da Seção Brasil do ITI. Coordenador do curso de Especialização em Implantodontia da ABORS. Clínica Privada em Porto Alegre/RS, dedicada à Cirurgia Bucomaxilofacial e Implantodontia. 